\title{
The Nature of the Motor Insurers' Bureau and Its Agreements
}

\author{
Time for a Radical New Approach?
}

\author{
Matthew Channon* \\ Lecturer in Law, University of Exeter, Exeter, United Kingdom \\ M.Channon2@exeter.ac.uk
}

\begin{abstract}
The Motor Insurers' Bureau (МІв) was formed in 1946 to provide compensation for victims of road traffic accidents from uninsured drivers and later untraced drivers. ${ }^{1}$ The мгв and its agreements have been criticised by academics due to potential gaps in coverage. ${ }^{2}$ The мів agreements are seen as 'an entirely novel piece of extra-statutory machinery,', due to not being based in statute and therefore without parliamentary control. This has brought challenges involving issues of transparency when new agreements are created. Claims against the м гв, particularly in relation to untraced drivers, have also been controversial. With the UK in a transition period in terms of its relationship with the EU and with the potential absence of a cause of action against the мIв post-transition period, the question arises as to whether the мгв should be put on a statutory footing.

This article therefore aims to explore whether the мів should be put on a statutory footing. It will examine the relationships between the мгв, its members, the state, and Parliament. It will further examine issues involving transparency and enforcement. It will go on to compare the Australian Capital Territory (ACT) approach in legislation with the United Kingdom (UK) approach, to see what will be gained or lost with the
\end{abstract}

* The author would like to thank Professor Rob Merkin QC, Professor Anne Barlow and Professor Andrea Lista for their comments and advice on this work. Any errors are the author's own.

1 Motor Insurers Bureau, 'Untraced Drivers Agreement' (2017) <https://www.mib.org.uk/ media/355104/amended-2017-untraced-drivers-agreement-england-scotland-and-wales_v10 .pdf $>$ accessed 21st February 2019.

2 See for example James Marson and Katy Ferris, 'The Uninsured Drivers' Agreement 2015 as a Legitimate Source of Authority' (2017) 38 (2) Statute Law Review, Pages 133-146, 146.

3 Halsbury's Laws of England see 709. 'Loopholes in third parties'statutory rights'. 
UK adopting the legislative route. It will then conclude on which, if any, examine potential reform options - radical or otherwise - might be usefully pursued to meet the criticisms of to the system in the UK.

\section{Keywords}

Motor Insurers' Bureau - motor insurance - Australian Capital Territory - EU Law and nominal defendant

\section{Introduction}

A claim against the мІв is seen as the last resort for the victims of road traffic accidents, who have no other route to compensation due to the driver of a vehicle being uninsured or untraced. The мг has been compensating victims of these drivers since 1946. The Uninsured Drivers' Agreement 2015 ('UDA 2015') and Untraced Drivers' Agreement 2017 ('UtDA 2017') ${ }^{5}$ are not based within statute, but rather agreements between the мів and the UK Secretary of State for Transport (SoSFT). The м IB plays other significant roles in the UK. For example, by managing the motor insurance database and is also the UK's representative on the Council of Bureaux. ${ }^{6}$ However, despite its successes, it will be argued here that there look to be good reasons now to take a different approach. In particular, given the added complications that Brexit poses in this field, has the moment come to countenance a radical overhaul of this area of regulation both to ensure greater transparency and to put the мIв on a statutory footing?

Controversy surrounds the MIB agreements involving claims. ${ }^{7}$ It seems that this is the result of EU motor insurance law, which regulates, inter alia, the compensation paid to victims of uninsured and untraced drivers across the EU, providing a high level of protection for victims. Cases such as Bernaldez ${ }^{8}$

4 Motor Insurers' Bureau, 'Uninsured Drivers' Agreement' (2015) <https://www.mib.org.uk/ media/166917/2015-uninsured-drivers-agreement-england-scotland-wales.pdf $>$ accessed 03 April 2020.

5 Motor Insurers' Bureau, 'Untraced Drivers' Agreement' (2017) <https://www.mib.org.uk/ media/355104/amended-2017-untraced-drivers-agreement-england-scotland-and-wales_v10 .pdf $>$ accessed 21 February 2019. When referred to together, the UtDA and UDA will be referred to as 'the agreements'.

6 See Council of Bureaux < https://www.cobx.org/> accessed 28 August 2019.

7 See for example the discussion from James Marson and Katy Ferris (n 2 ) 146.

8 C-129/94 Ruiz Bernáldez, Criminal proceedings against [1996] All ER (EC) 741. 
and Candolin ${ }^{9}$ from the EU courts have increased the protection provided by EU law for third party victims, and the мів agreements have been the subject of a number of disputes regarding compliance with EU law. For example, in Delaney $v$ Secretary of State for Transport ${ }^{10}$ the SoSFT was successfully sued in a Francovich ${ }^{11}$ action for the 1999 Uninsured Drivers' Agreement's ${ }^{12}$ (clause 6 (1) (e) (iii)) breach of EU law relating to the compensation provided to those who commit an illegal act. ${ }^{13}$ With the UK officially having left the EU, and the future arrangements for after the transition-period finishes having not yet been agreed, this cause of action against the Secretary of State for Transport (SoSFT) could come to an end. ${ }^{14}$ This would leave a crucial gap. The introduction

$9 \quad$ C-537/03 Candolin and others $v$ Vahinkovakuutusosakeyhtio Pohjola and another [2005] All ER (D) 375 .

$10 \quad$ Delaney $v$ Secretary of State for Transport [2015] 3 All ER 329.

11 C-6/9o Francovich v Italian Republic [1991] E.C.R. I-5357.

12 Motor Insurers' Bureau, 'Uninsured Drivers' Agreement' (1999) <https://www.mib.org.uk/ media/166947/1999-uninsured-drivers-agreement-england-scotland-wales.pdf $>$ accessed 02 March 2020.

13 The crime exception was introduced in clause 6 (1) (e) (iii) of the Motor Insurers' Bureau, 'Uninsured Drivers' Agreement' (1999) <https://www.mib.org.uk/media/166947/1999uninsured-drivers-agreement-england-scotland-wales.pdf.> accessed 02 March 2020.

14 The 'Withdrawal Agreement' currently governs the UK and EU's relationship. The UK will continue to apply EU law until the end of the transition period (31st December 2020). See article 4 (1) of the Withdrawal Agreement which notes, 'The provisions of this Agreement and the provisions of Union law made applicable by this Agreement shall produce in respect of and in the United Kingdom the same legal effects as those which they produce within the Union and its Member States. Accordingly, legal or natural persons shall in particular be able to rely directly on the provisions contained or referred to in this Agreement which meet the conditions for direct effect under Union law'. Article 127 (1) of the Withdrawal Agreement, amongst a number of other things, notes, 'Unless otherwise provided in this Agreement, Union law shall be applicable to and in the United Kingdom during the transition period'. Under article 86 (1) of the Withdrawal Agreement, the Court of Justice of the EU (CJEU) continues to have jurisdiction in any proceedings brought by or against the United Kingdom before the end of the transition period. See also article 87 of the Withdrawal Agreement surrounding new cases. HM Government, 'Agreement on the withdrawal of the United Kingdom of Great Britain and Northern Ireland from the European Union and the European Atomic Energy Community' (October 2019) <https:// assets.publishing.service.gov.uk/government/uploads/system/uploads/attachment_ data/file/840655/Agreement_on_the_withdrawal_of_the_United_Kingdom_of_Great_ Britain_and_Northern_Ireland_from_the_European_Union_and_the_European_Atomic_ Energy_Community.pdf> accessed 02 March 2020. The UK could obtain an extension for up to two years after the transition-period (article 132 of the Withdrawal Agreement), although this is unlikely. Section 33 of the UK's European Union (Withdrawal Agreement) Act 2019 which inserted Section 15A into the European Union (Withdrawal Agreement) Act 2018 states that 'A Minister of the Crown may not agree in the Joint Committee to an extension of the implementation period'. Also see Section 7 European Union (Withdrawal) Act 2018. 
of legislation, whilst not remedying this completely, could enable an additional claim against the мгв in the courts. This would signify the equivalence of victims of uninsured and untraced drivers with those who are injured by an insured vehicle.

The мів has, particularly over the past two decades, faced calls from scholars to reform its agreements. ${ }^{15}$ This is both in terms of the substance of the agreements, and concerning EU law compliance. This article focusses on whether the мів should be given statutory force, rather than just the substance of the agreements. Moreover, this article starts with the premise that the мІв should not be removed altogether due to its critical role in the Council of Bureaux and maintenance of the Motor Insurance Database. Any counterarguments are not the focus of this article. In drawing its conclusions, an important comparison will be made between the UK and the ACT, to examine the potential effectiveness of suggested reform based on the ACT approach. It is hoped that this analysis will provide a unique and timely insight into these important issues, which have been long neglected from a UK perspective. In so doing, it will draw attention to the need to focus on the shortcomings of the non-statutory scheme in the UK, which has received little legislative scrutiny or evaluation.

This article will therefore examine some of the key challenges relating to the MIB, and challenges which would be faced by putting it on a statutory footing. It will begin by examining the background of the мІв, as well as its current status, providing an interesting indication in terms of the challenges the мIв has faced. It will further discuss the relationship between the мів and its members, as well as the State, and Parliament. This will indicate potential influences on the MIB's agreements and challenges which could be faced by changing these influences post-transition outside of the EU. The second part of the article will examine the АСт approach and whether this would work well in the UK, an exercise never before undertaken. As noted above, whether the мIB should be replaced is not discussed here, but rather whether its responsibilities should be embedded in statute. Finally, the article will conclude by weighing up the potential benefits of statutory reform against the difficulties of such a new approach and consider the possibilities of reform.

15 Nicholas Bevan has written articles critical of the мів, for example Nicholas Bevan, 'No through road', New Law Journal 165 (7648) (2015) 7, and Nicholas Bevan, 'A call for (more) reform' New Law Journal 165 (7661) (2015) 9. Also see James Marson and Katy Ferris (n 3). Also see James Marson and Katy Ferris, 'Motor vehicle insurance law: ignoring the lessons from King Rex', Business Law Review 38 (5) (2017) 177-186. 
It is important to first examine the formation and development of the MIB, which will highlight that the compensation of uninsured and untraced drivers has always been complex and controversial. The мів was formed in June 1946. Prior to this, where the responsible party of a road accident was uninsured or untraced, the third party victim would be uncompensated, unless they found, and consequently sued, the uninsured driver for compensation. This was undoubtedly a significant issue for the victim. The introduction of the M Iв arose from a report of a Committee on the Board of Trade in 1937, led by Sir Felix Cassel. The Committee was composed of representatives from insurance companies and Lloyds, to examine a number of issues with compulsory insurance, including in relation to uninsured drivers. ${ }^{16}$ In the Report, the Committee noted that:

'We are conscious of the fact that by so doing (setting up a central fund) we are providing for the road user injured by a motor vehicle a source of compensation which is not available to any other person suffering at the hands of a delinquent. Such a course, however, appears to us to be a natural consequence of the establishment of compulsory insurance, with its implication that every person injured by a motor vehicle should have the benefit of insurance'17

This highlights the unique nature of such a fund. Interestingly, the MIB was formed nine years later with, 'a threat of state control in the background'. ${ }^{18}$ The MIB undertook two agreements, the first, an Uninsured Drivers' Agreement with the Minister of War Transport, and the second, an agreement with individual insurance companies (as well as insurance syndicates). ${ }^{19}$ In 1945 , the Minister of War Transport noted that, 'Legislation to give effect to the scheme proposed by the (Cassel) Committee would be somewhat complicated, and I am glad to say that the insurers have made proposals for a voluntary scheme on similar

16 As noted by Christopher Shawcross and Michael Lee, the Law of Motor Insurance (Butterworth and Co, 1949), 362 .

17 Board of Trade, 'Report of the Committee on Compulsory Insurance' (1937) cmd 5528, [164].

18 Professor Richard Lewis, 'Insurers' Agreements Not to Enforce Strict Legal Rights: Bargaining with Government and in the Shadow of the Law', (1985) 48 (3) Modern Law Review (1985) 275, 280.

19 Shawcross and Lee (n 16). 
lines which I am satisfied will achieve the same purpose.20 Interestingly the courts have later noted confusion surrounding the introduction of extra-statutory arrangements compared to legislation. As noted by Lord Diplock in Gurtner v Circuit and another, ${ }^{21}$ 'What reasons influenced the Government to adopt this oblique and extra-statutory way of imposing liability upon the bureau, despite the legal complications this involves, I do not know.'22 This is an interesting point. In both statutory and non-statutory uninsured vehicle arrangements, legal complications were present. However, it is not entirely evident as to what complications concerning a statutory arrangement were foreseen. At the time, there would have been concerns surrounding how a statutory arrangement would work in practice, i.e. protections required to compel insurers against their will. Nevertheless, Christopher Shawcross noted, 'The insurers have by this bold gesture taken upon themselves a great burden, in that they have agreed to shoulder the financial responsibilities of errant motorists in the absence of satisfaction by these wrongdoers.' ${ }^{23}$ Further, Shawcross stated that the мів agreements went much further than the Cassel Committee proposals, by, imposing liability on all insurers' for all third party claims under the Road Traffic Acts.' ${ }^{24}$ Overall, it is evident that the introduction of the MIB significantly restricted the right of insurers to avoid liability to third parties (although they could repudiate claims against the insured).

However, the MIB were only required to compensate victims of uninsured drivers, any payment made to victims of untraced drivers was ex gratia. Interestingly, the original Cassel Committee Report did not recommend that victims of untraced drivers should be compensated. ${ }^{25}$ Nevertheless, the MIв stated in clause 6 of the original agreement that while they had no legal obligation to compensate the victims of untraced drivers, 'where there is reasonable certainty that a motor vehicle was involved and that except for the fact that the

20 Uninsured Motorists (Accidents, Compensation) HC Deb 12 November 1945, 1869W. Of course, it is worth noting here that due to the nature of the мів agreements there was not a requirement under them for the мгв to compensate victims due to the fact that third parties were not part of the contract between DfT and м в (this will be discussed further later), 'In practice, however, it was unthinkable that the мIв would violate the Agreements, and if it had done so it is likely that the scheme - or some alternative - would have been put onto a statutory footing'. See Peter Cane and James Goudkamp, Atiyah's Accident Compensation and the Law (Cambridge University Press, 2018), 244.

$21 \quad$ [1968] 2 Q.B. 587.

22 Ibid, 603.

23 Shawcross and Lee (n 16), 279.

24 Ibid, 364.

25 Noting that, 'the grant of a right against the Central Fund would be calculated to lead to such abuses as to render such a course totally unsuitable. Cassel Committee (n 17) [168]. 
vehicle, owner or driver cannot be traced, a claim would lie, the Bureau will give sympathetic consideration to the making of an ex gratia payment to the victim, or his dependants. ${ }^{26}$ There was, however, significant lobbying by Parliament for this to change, due to instances whereby victims were not receiving redress after being injured by an untraced driver. ${ }^{27}$ Eventually the UtDA was introduced to provide redress to victims, although with limitations, such as in relation to property damage. Nevertheless, the complexity surrounding the introduction of the м Ів was evident, including the form it should take and its remit. The above synopsis highlights that the introduction of the MIB was not simple, and it took a significant degree of compromise and goodwill. The MIв then enhanced coverage further to comprise victims of untraced drivers in response to significant pressure to do so. The coverage provided by the MIB is therefore not static, and there are external influences in terms of coverage that is achievable. This can lead us to the question of whether legislation is required to increase protection, and this is a matter to which we return.

The MIв and Relationship with Members, the Secretary of State for Transport and Parliament

This section will now examine the relationship between the мIв, its members, the state, and Parliament. It will seek to explore any complexity in these relationships, and further whether the extra statutory approach taken is beneficial in these relationships.

\subsection{Members}

The MIв is a company limited by guarantee registered in England and Wales. Insurers who wish to partake in motor insurance business in the UK must be a member of the MIB and contribute to its funding. ${ }^{28}$ The contribution of members is proportionate to their fee income from motor insurance business. This, therefore, means that the eventual cost of running the MIB rests with all insurance paying drivers through insurance premiums. Interestingly, the requirement for insurers to contribute to the мів is the sole part of the Road Traffic Act 1988 (RTA 1988) which contains the мів. ${ }^{29}$ The agreements are between the

26 Hansard HC Deb o5 March 1965 vol 707 cc1814-24 at 1816.

27 Hansard HC Deb o1 December 1965 vol 721 cc1419-21.

28 Without such membership or contribution, the motor insurer is no longer deemed an 'authorised insurer' and will be unable to undertake motor insurance business in the UK (Section 145 (6) RTA 1988).

29

Section 145 (5)-(6) RTA 1988. 
SoSFT and the MIв. An individual wishing to receive compensation must meet the terms of the мгв agreements and must submit their claim to the мгв. As members of the MIB, insurers can vote at meetings, and can nominate individuals to be on the MIB's technical committee. This therefore highlights control from members. ${ }^{30}$

The MIB's relationship with its members is found in its Articles of Association. ${ }^{31} \mathrm{An}$ interesting aspect of the MIB's Articles of Association is article 75 . This provides that where a claim is made against the мів and the driver has insurance (albeit invalid), the insurer will compensate the victim as an agent for the MIв. Compensation will be made under the UDA 2015, not the original insurance policy. UK legislation through the RTA 1988 allows this by not removing potential restrictions on coverage. For example, Section 148 (2) RTA 1988 limits certain exclusion clauses, meaning that insurers can use exclusions other than those within Section 148 (2) RTA 1988. While this seems reasonable, it is controversial, as under EU law the insurer should be compensating the third party, and this should be within the insurance policy and not the мів Agreement. Cases from the CJEU such as $C$ sonk $\boldsymbol{a}^{32}$ have noted that compensation should only be provided under the compensation body arrangements 'where no insurance policy exists'. UK case law, however, has not followed this. ${ }^{33}$ The benefit of an insurer using an exclusion clause is unclear, as they would likely be required to pay under article $75{ }^{34}$ Nevertheless, this highlights a complex relationship between insurers, the $\mathrm{MIB}$, and statute. Insurers being part of the MIB's governance provides positives by utilising the expertise of the insurance market. The potential limitation of such expertise if legislation was introduced, could be problematic. ${ }^{35}$

It is also notable that where there is a dispute between motor insurers involving article 75, this is dealt with through arbitration, 'Unless the Bureau and the Member agree an alternative method for dispute resolution'. ${ }^{36}$ There is also the

30 Article 74 (2) Motor Insurers' Bureau 'Articles of Association' < https://www.mib.org.uk/ media/462763/2019-mib-articles-of-association-030719.pdf > accessed 22 August 2019.

31 See Motor Insurers' Bureau 'Articles of Association' <https://www.mib.org.uk/media/ 462763/2019-mib-articles-of-association-030719.pdf > accessed 22 August 2019.

32 C-409/11 Csonka v Magyar Allam [2013] All ER (D) 243, [31].

33 See for example Sahin v (1) Havard (2) Riverstone Insurance (UK) Ltd [2016] EWCA Civ 1202.

34 Although note that the UDA 2015 clause 6 (1) does not allow subrogated claims, therefore use of an exclusion clause, could mean another insurer compensating and unable to subrogate the claim (see for example Bristol Alliance Ltd Partnership $v$ Williams [2012] EWCA Civ 1267). Also for limitations of the м в а agreements compared to claims under the insurance policy see below.

35 Note that claims and arbitration will be discussed below.

36 мів Articles of Association (n 30), article 75 (5) (f). 
potential to appeal an arbitration ruling to a court. ${ }^{37}$ An example of this is in Haven Insurance Company Limited vEUI Limited (t/a Elephant Insurance $)^{38}$ whereby the insurance company was deemed to be out of time in making a claim to the arbitrator, as article 75 was unclear on the notice to be given by an insurer. This again highlights a complexity with article 75 which can be the subject of dispute. Further, article 75 provides some flexibility for the MiB's ability to settle claims. For example, the м Iв can settle claims itself 'if it appears to the Bureau to be expedient. ${ }^{39}$ Both this and the MIB's provision for methods of dispute resolution between insurers are examples of some of the flexibility involved in the current regime. Any future legislation would need to consider any impact of the potential removal of flexibility on both the insurance industry and the victim. In the latter example involving the MIB's ability to settle claims, the removal of this could mean further delays in compensating the victim. This is not to say that legislation would automatically remove such flexibility although it requires careful consideration.

Overall it is clear that the MIB's relationship with insurers is one of collaboration. Members have voting rights and can attend meetings of the MIB; they are also consulted with. As noted above, this article is not concerned with whether the мів should be scrapped, but rather whether the agreements should be put on a statutory footing. The insurance industry have knowledge and experience of, the insurance market. While this expertise would not necessarily be removed through the introduction of legislation, maintaining such expertise is an important consideration in any future legislation.

\subsection{State Control}

As the agreements are between the мів and the SoSfT, there is undoubtedly government influence here. The MIB is not self-regulating with the ability to determine whether and how it compensates victims. The relationship between the мів and the State has been discussed on a number of occasions, as vertical direct effect of Directives can only be used against the state or its emanation. The мів is a company limited by guarantee, and therefore questions concern whether it is an 'emanation of the state'. One of the requirements of 'emanation of the state' is state control, although this need not be on the day to day running of the body. ${ }^{40}$ In Silverton $v$ Goodall, ${ }^{41}$ the High Court noted that the MIв was

37 Although as will be discussed below, this is challenging.

38 Haven Insurance Company Limited v EUI Limited (t/a Elephant Insurance) [2018] EWHC 143 (Comm).

39 Sеe мів Articles of Association (n 3o) article 75 (4) (a) мів Articles of Association.

$40 \quad$ Griffin $v$ South West Water Services [1995] IRLR 15.

41 [1997] P.I.Q.R. P451. 
an emanation of the state, 'having regard to the history of the formation of the $M I B$, and of the making of the successive agreements between the Minister and the MIB, without which no doubt further legislation would have been passed'.42 This highlights that the agreements were made against a backdrop of potential legislation, which could be a factor in negotiations. Interestingly, in the joint appeals to the Court of Appeal in Mighellv Reading and another, ${ }^{43}$ Hobhouse LJ was of the view that the M Iв was not an emanation of the state, noting that, 'the Bureau was brought into existence by the insurance companies which were its original members. It provided a vehicle through which those independent insurance companies could enter into private law agreements with the Secretary of State', ${ }^{44}$ In Byrne $v$ мIв and Another, ${ }^{45}$ Flaux J held that the MIв was not an emanation of the state and did not fulfil the state control function. His lordship compared the MIв to Griffin $v$ South West Water ${ }^{46}$ involving significant powers of control provided through statute to the state, whereas in the case of the мів, 'there are no equivalent powers of control given to the Secretary of State' ${ }^{\prime 7}$ Consequently, despite the State being able to legislate, there is currently no legislation. Later interpretation of EU law in Farrell $v$ Whitty $(\mathrm{No} 2)^{48}$ has found that the requirements of emanation of state are not compulsory, and 'state control' is not necessarily required. This case concerned the мІв in Ireland, which the CJEU held was an emanation of the state due to its function and later case law in the UK has found that the UK's MIB is an emanation. ${ }^{49}$ Nevertheless, the UK's relationship with the EU at the time of writing is likely to change due to the UK's imminent departure from the EU's jurisdiction posttransition. The impact of this will be discussed below in relation to the enforcement through EU law. It is clear overall that there is not a significant amount of control on the day to day running of the мів from the state. The

42 Ibid, 463 .

43 White $v$ White; Evans v Motor Insurers Bureau; Mighell v Reading [1999] 1 C.M.L.R. 1251. Moreover, In White $v$ White and another [2001] UKHL/g. Lord Scott noted, obiter, that the MIB was not an emanation of the state, without providing much detail on this.

44 Ibid, [72].

45 [2007] EWHC $1268(\mathrm{QB})$.

46 Griffin $v$ South West Water (n 40).

47 Ibid, [59].

$48 \quad$ Farrell $v$ Whitty (no 2) [2018] Q.B. 1179.

49 The latter case of Lewis $v$ MIB [2019] EWCA Civ 909 the UK has found that the MIB is an emanation of the state based on the reasoning in Farrell. For commentary on Lewis see James Marson and Katy Ferris, 'The compatibility of English law with the Motor Vehicle Insurance Directives: the courts giveth...but will Brexit taketh away?' Law Quarterly Review 136 (Jan) (2020) 35-40. 
MIB contracts with the SoSFT, and this, therefore, ensures a degree of consent required from the мів in terms of how it is run.

\subsection{Parliament}

Parliament, and its current role is important due to this article's focus on the potential introduction of legislation. It is notable that there have been a number of questions asked in Parliament concerning the мів and how it operates. For example, in 1990 the parliamentary under-secretary for Transport was asked:

(1) how many complaints he has received about the operation of the Motor Insurers Bureau for each of the last five years; and if he will make a statement; (2) if he will give his reasons for his decision to allow the Motor Insurers Bureau to be regulated by a voluntary agreement; (3) if he will make a statement about the operation of the Motor Insurers Bureau; (4) if he will review the voluntary agreement operated between his Department and the Motor Insurers Bureau; and if he will make a statement; (5) what representations he has received about the operation of the Motor Insurers Bureau. ${ }^{50}$

This is an implied criticism of the Мाв, particularly the voluntary nature of the agreements. The response from the under-secretary was, inter alia, that, 'these arrangements have worked satisfactorily... I have no plans to review the agreements. ${ }^{51}$ There was no criticism from the under-secretary involving the voluntary nature of the agreements, representation received, nor the number of complaints received. This therefore highlights a challenge in terms of transparency. Information as to how complaints are dealt with should be available to highlight any issues and potential challenges which are being faced by victims and the мів. Transparency will be examined below in further detail.

Nevertheless, Parliament has at times put pressure on the government in terms of the MIB's remit, for example in relation to victims of untraced drivers, ${ }^{52}$ although this does not show significant control. However, it is worth noting the indirect role that legislation through Parliament has on the MIB's coverage. The MIB covers situations involving an absence of compulsory insurance, it does not cover situations where insurance is not compulsory. Hence, if legislation alters the compulsory insurance requirements within Section 145

5o HC Deb o5 February 1990 vol 166 c513W.

51 Ibid.

$5^{2}$ See above. 
RTA 1988, this would automatically alter the coverage of the agreements. An example can be found when the RTA 1988 was amended by the Motor Vehicles (Compulsory Insurance) Regulations 2000 which extended the compulsory insurance requirements to 'other public place'. This consequently highlights some control over the coverage of the agreements from Parliament.

Of course, Parliament could pass legislation expressly regulating the мів. However, the impact of this in terms of the current agreements is uncertain. For example, if Parliament chose to continue with the current мів agreements, and add statutory provisions regulating the МІв, this could introduce confusion and conflict for victims. Moreover, issues could surround the absence of consent from the insurance industry and the potential removal of flexibility and expertise. Nevertheless, transparency and enforcement could potentially be increased, which leads us to the next part of this article.

The Miв Agreements, Transparency and Enforcement

As noted above, the agreements are an extra-statutory mechanism to provide compensation to victims. There are challenges surrounding this in terms of transparency and enforcement which we will now examine.

\subsection{Transparency in the Introduction of New Agreements}

With the absence of the need for agreements to go through Parliament to become effective, parliamentary debates in Hansard are largely unavailable when discussing the purpose and interpretation of the agreements. ${ }^{53}$ When a case is brought before a court to determine the interpretation of the agreements, there is potential for the courts to rely on discussions between the MIB and the Government. However, it appears on occasion that the courts have been critical of the lack of evidence surrounding the introduction of certain provisions. For example, in Delaney $v$ Secretary of State for Transport, ${ }^{54}$ concerning state liability for an exclusion contained in the UDA $1999,{ }^{55}$ Jay J in the High Court noted that:

As regards the evidence, the judge said that there was a conspicuous paucity of it; there were no documents bearing on the decision to introduce the crime exception into the Uninsured Drivers' Agreement...The clause

53 Whereas they are in relation to the construction of statute see Pepperv Hart [1993] AC 593.

54 Delaneyv Secretary of State for Transport [2014] EWHC 1785 (QB).

55 Involving those who commit a criminal act. Clause 6 (1) (e) (iii) Uninsured Drivers Agreement 1999 . 
was introduced for the first time into the 1999 version. The decision to introduce it was undocumented. There was a November 1996 letter referring to a draft of the revised agreement but throwing no light on the decision to add the clause. ${ }^{56}$

This highlights a challenge for the courts, with Hansard unlikely to assist judicial interpretation. This is further problematic due to the limits of available communication between the SoSFT and the мIB. A statutory regime could consequently ensure that there is greater transparency in the introduction of agreements, and make it easier for the courts. Moreover, it would importantly provide claimants and their legal advisors with important information in order to interpret the agreements. However it is notable that the MIв provide 'Notes for Guidance' for both their UDA $2015^{57}$ and UtDA 2017, ${ }^{58}$ which are found on their website. Conversely, these are not particularly lengthy, nor do they provide enough in terms of the intention behind the introduction of the provisions.

Moreover, M Ів agreements are not introduced without input. For example, in 2013, the DfT undertook a public consultation on the MIB UDA and UtDA, and noted that, 'We recognise the valuable work that the мIв has already done with Association of Personal Injury Lawyers (APIL) and Motor Accident Solicitors Society (MASs) to discuss and resolve issues under the Uninsured Drivers' Agreement. ${ }^{5}$ Consultation responses were also published by the DfT. When the UDA 2015 was introduced, the DfT produced a 'Final Consultation Outcome', ${ }^{\prime 0}$ providing detailed discussion of some of the changes made to the UDA 1999, and the rationale behind these. However, some of the additions to the agreement were not discussed in significant detail. For example, the introduction of a terrorism exclusion into the agreement (clause 9) was discussed

$56 \quad$ Delaney ( $\left.\mathrm{n}_{54}\right),[42]$.

57 Motor Insurers' Bureau, 'Notes for Guidance: Uninsured Drivers' Agreement' (2015) <https://www.mib.org.uk/media/352780/2015-uninsured-drivers-agreement-notes-forguidance-v2-o.pdf > accessed 2 September 2019 .

58 Motor Insurers' Bureau, 'Notes for Guidance: Untraced Drivers' Agreement' (2017) $<$ https://www.mib.org.uk/media/358739/untraced-notes-for-guidance-vio.pdf > accessed 2 September 2019.

59 Department for Transport, 'Statement of intent on the Consultation on the Review of the Uninsured and Untraced Drivers' Agreements' <https://assets.publishing.service.gov.uk/ government/uploads/system/uploads/attachment_data/file/439697/statement-ofintent.pdf $>28$ August 2019 .

6o Department for Transport, 'Department for Transport Response to the consultation on the Review of the Uninsured and Untraced Drivers' Agreements' <https://assets.publishing.service.gov.uk/government/uploads/system/uploads/attachment_data/file/442476/ response-uninsured-drivers-agreement-pdfa-2a.pdf > accessed o2 September 2019. 
only briefly in the response. Interestingly, the exclusion was later removed from the agreement by the Supplementary Uninsured Drivers' Agreement 2017 (clause 3) $\cdot{ }^{61}$ Consequently whilst some context was provided behind the new agreement, communication of intention could be improved. There are, of course, going to be private discussions with private agreements, although any significant change to the MIв regime, it is submitted, could and should have further scrutiny. An agreement enshrined in legislation would have had such scrutiny, with a number of stages in the House of Commons and House of Lords, along with a Committee and Report stage. Interestingly, the Supplementary Uninsured Drivers' Agreement 2017 was not subject to public consultation. This was a less substantial agreement which amended or removed certain provisions of the UDA 2015, (such as the terrorism exclusion) and there were no significant additions. Overall, therefore, the limits of transparency when the м Ів agreements are introduced is concerning and reform is needed, the method of potential reform will be discussed later.

\subsection{Transparency in Claims and Arbitration}

The мів claims process is not straightforward. There are a number of challenges which need to be addressed in this part, including transparency, limits of appeal, and the appointment of arbitrators. The introduction of legislation here may be beneficial, as will now be discussed.

There are differing claims processes for victims of uninsured and untraced drivers. In relation to uninsured drivers, victims can sue an uninsured driver in court for damages, the MIB will then compensate for any unsatisfied judgments. However, 'In practice, most cases do not actually proceed to court. The MIB prefers to reach an agreement to pay compensation without going to court, ${ }^{62}$ although with the need for driver consent. ${ }^{63}$ Under the UtDA 2017, as there is no identifiable claimant, claims are made directly to the мгв. ${ }^{64}$ Clause 11 of the UtDA 2017 notes:

61 Motor Insurers' Bureau, 'Supplementary Uninsured Drivers' Agreement' (2017) <https:// www.mib.org.uk/media/350345/2017-supplementary-uninsured-drivers-agreementengland-scotland-and-wales.pdf> accessed o3 April 2020. In Roadpeace, the High Court found that the terrorism exclusion had breached EU law.

62 Timothy Edmunds, 'Uninsured Drivers and the Motor Insurers' Bureau' (17th November 2015) House of Commons Briefing Paper <https://researchbriefings.parliament.uk/ ResearchBriefing/Summary/SNo1997\#fullreport> accessed 2 September 2019.

63 Ibid, 8.

64 In 2019, the Supreme Court (SC) in Cameron v Liverpool Victoria Insurance Co Ltd (Motor Insurers' Bureau intervening) [2019] UKSC 6 were asked to determine whether a victim could sue an unidentified driver in court. The SC, noted, inter alia, that: 'In the first place, the Road Traffic Act scheme is expressly based on the principle that as a general rule there is 
Subject to clauses 3 to $10, M I B$ shall, by adopting the same method as a court in England, Wales or Scotland (as appropriate) would adopt, be obliged to make an award or interim payment only if it is satisfied, on the balance of probabilities, that the death, bodily injury or damage to property was caused in circumstances such that the unidentified person would (had he been identified) have been liable to pay damages to the claimant.

This provides that the MIB is responsible for determining the liability of the person who caused the accident, and damages which would have been payable if the person was identified. Moreover, under clause 11 (2), the мIв is entitled to determine whether any damages are to be reduced due to the contributory negligence of the victim. Whilst this provides some insight into the workings of the мІв, it is nevertheless challenging, due to the мІв attempting to predict the court's actions as if the vehicle had been identified. Further, the MIB is a commercial organisation with members who are insurance companies, and therefore the potential for bias has been pleaded by claimants. ${ }^{65}$ The determination of liability and damage is also difficult, as one of the parties involved in the accident involving an untraced vehicle would not be present to provide details of the accident. Moreover, as was noted in Carswell $v$ SoSFT an untraced driver claim, 'demands a system different to a certain extent, because, by definition, the driver at fault cannot be identified and pursued through adversarial procedures' ${ }^{\prime 6}$ This is an important point. The absence of a driver is a challenge, as there is no judgment obtained against the responsible driver.

It is worth noting that if the claimant is unsatisfied with how their claim is handled under the UtDA 2017, they can appeal to an arbitrator (this will be discussed below). Of course, there are some limits with the MIB's power to determine awards such as when the victim is a minor ${ }^{67}$ or lacks capacity under

no direct liability on the insurer, except for its liability to meet a judgment against the motorist once it has been obtained...The availability of compensation from the Bureau makes it unnecessary to suppose that some way must be found of making the insurer liable for the underlying wrong when his liability is limited by statute to satisfying judgments' [22]. This therefore highlights that there is not an opportunity for a claim against an untraced driver, instead the victim will need to comply with the rules of the мів UtDA 2017 claims process, therefore providing a differing approach to the UDA.

65 See for example the claimant in Carswell $v$ Secretary of State for Transport [2010] EWHC $3230(\mathrm{QB})$ which will be discussed below.

66 Ibid, [71].

67 See clause 14 (1) (a) of the UtDA in terms of the definition of a minor. 
the Mental Capacity Act 2005. The determination of the award's fairness will be provided by an arbitrator. ${ }^{68}$

The legality under EU law of the MIB's process was discussed by the Court of Justice of the European Union (CJEU) in Evans. ${ }^{69}$ The CJEU noted that the $\mathrm{UtDA} 2003^{70}$ did not render it, 'practically impossible or excessively difficult' ${ }^{71}$ to exercise the right to compensation. The court recognised the appeals process from an мів decision, and further that the agreement's procedures provide the 'advantages of speed and economy of legal costs. ${ }^{72}$ This is an interesting point and an advantage of using a private system that does not need court intervention at first. If a statutory system mandated the court to determine the damages for untraced vehicles, legal costs could be increased as well as the time taken to compensate. The мів was criticised by the applicant in Carswell $v$ $S_{\text {SoSFT3 }}$ who noted that the scheme in the UtDA 2003 is 'fatally flawed' because, 'the MIв is not independent. As it comprises all motor insurers (who are companies run for profit), it is commercially interested in the outcome of any claim; and it is both investigator and the body liable to pay any award'. ${ }^{74}$ This was rejected by the court, first because this is an inquisitorial system, and second, because a different system was needed due to the absence of a driver. The court further noted that just because the мів was a commercial organisation,

68 Note that there were challenges in a Judicial Review in Regina (RoadPeace Ltd) $v$ Secretary of State for Transport [2018] 1 W.L.R. 1293. First, because the 2003 agreement did not provide this, and therefore as the agreements do not act retrospectively, the absence of this pre-2017 was a breach of the EU law principle of equivalence. The High Court rejected this and inter alia noted, 'This has been a long-standing process in respect of which there has been, so far as I am aware, no complaint by the European Commission; nor have I seen evidence of real problems on the part of minor or protected claimants in obtaining satisfactory awards under the UtDA, which would not have been found in a CPR claim against an insured

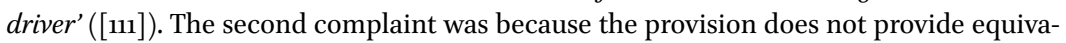
lent protection as under C PR (Civil Procedure Rules 1998/3132) Part 2.1 which provides the requirement of a litigant friend as well as the requirement that a barrister writes on the sufficiency of an award. This was again rejected due to the differences between the UtDA and the CPR, for example noting that 'if one compares a claim in respect of an unidentified driver with a claim in respect of an identified, insured driver, which would be governed by the $C P R$, the differences are quite significant', [110].

69 (C-63/01) Evans $v$ Secretary of State for the Environment, Transport and The Regions [2004] R.T.R. 32 .

70 Motor Insurers' Bureau, 'Untraced Drivers' Agreement' (2003) <https://www.mib.org.uk/ media/166886/2003-england-scotland-and-wales-untraced-drivers-agreement.pdf> accessed 21 February 2020.

71 Ibid, [54].

72 Ibid, [53].

73 Carswell (n 65).

74 Ibid, [27]. 
this, 'is not determinative', and 'whether a body is a proper body to carry out the relevant investigatory function will depend upon all of the circumstances.' ${ }^{75}$ Moreover, the court stated that 'safeguards' were present such as through arbitration, obtaining legal advice, and enforcing the MIB's obligation to investigate. ${ }^{76}$ Arbitration is particularly important for this article as it has been the subject of controversy, with concerns surrounding the appointment of arbitrators, as well as the ability to appeal the decision of an arbitrator. Under clause 18, the SoSFT shall appoint an arbitrator from a panel of Queens Council. ${ }^{77}$ As noted by the мів, ${ }^{78}$ 'These senior barristers will be appointed because they are considered to have the necessary experience and expertise to adjudicate upon the range of issues which might possibly arise under the Agreement'. Nevertheless, particular concerns surround the partiality of arbitrators. In Evans, ${ }^{79}$ the Advocate-General (A-G) noted that:

one must, it seems, proceed, according to the submissions of the parties to the present proceedings, on the basis that the Queen's Counsel featuring on the lists described provide every guarantee as to their independence. That notwithstanding, the question still arises as to whether, in view of their procedural situation and their proximity to the $M I B$, they also provide the same guarantee as to their impartiality. ${ }^{80}$

75 Ibid, [72]. An interesting comparison between the мів and the Criminal Injuries Compensation Authority (CICA) was made by the claimant, with the мІв representing commercial interests, whereas CICA investigates claims as an arm of government. However, the court noted the similarities between the two, with both CICA and MIв payments paid out of the public purse. The мів are paid for by motorists. The court noted [74] that, 'any increase in the levels of payout by the MIB is more likely to affect premium rates than profitability'. This is an interesting point, although it is submitted is not conclusive in terms of the criticism of the мів by the claimant in Carswell. It is worth noting that the мів have previously stated concerns surrounding premium increases and a consequential increase in uninsured driving. Moreover, the court in Carswell noted that [74], 'The extent to which the effects of payouts on the profitability of insurance companies would impact on those involved in settling MIB claims is therefore, at highest, very uncertain indeed'.

76 Carswell (n 65), [76].

77 It is important to note that the UDA further provides arbitration under clause 17 in relation to two requirements contained within provisions of the UDA and their reasonableness. The first is in relation to the form of the claim and the information which is required be provided by the claimant to the мів (clause 12), and the second in gaining a judgment (if required by the мгв) against the person who is liable for the accident (clause 14).

78 See Motor Insurers' Bureau, 'Untraced Drivers' Agreement 2017: Notes for Guidance' (2017) <https://www.mib.org.uk/media/358739/untraced-notes-for-guidance-v1o.pdf> accessed 28 January 2020, page 21.

79 Evans (n 69).

80 Ibid, [AG97]. 
The CJEU in Evans found that the arbitration procedure fulfils EU law, as the arbitrator is, 'appointed under conditions which ensure that he is independent and that he makes his award after making his own assessment of the information in the file. ${ }^{81}$ In Application for Permission Kennedy, ${ }^{82}$ the claimant sought Judicial Review on a number of grounds, one being the partiality of the arbitrator. The claimant argued that the arbitrator had shown bias in making an order which the мів did not seek. ${ }^{83}$ This again was rejected as there was 'no evidence of bias' shown here. ${ }^{84}$ Further, the claimant contended that there was a breach of article 6.1 of the European Convention on Human Rights (concerning a right to a fair trial), and therefore the award should be set aside due to the absence of independence and impartiality from the arbitrator. Again this was rejected by the High Court.

An additional concern from the A-G in Evans surrounded the absence of a public hearing and an opportunity for claimants to be involved in the negotiations between the MIB and arbitrators. ${ }^{85}$ The CJEU noted that in relation to arbitration that victims must be aware, 'of any matter that might be used against them and have an opportunity to submit their comments thereon' ${ }^{86}$ Further, it is notable that an arbitration can only be appealed on a point of law, rather than on the case facts. Clause 16 (2) (c) UtDA 2017 provides that the claimant or authorised person will provide an undertaking that the claimant will abide by the arbitrator's decision. ${ }^{87}$ In Harvey v Motor Insurers' Bureau, ${ }^{88}$ the High Court rejected an appeal by the claimant, concerning the fact that the arbitrator found that there was no basis for any award (as there was no evidence of

\footnotetext{
81 Ibid, [50].

$82 \quad[2001]$ EWHC Admin 851.

83 This was set off of damages with costs awarded to the defendant in a case in the county court.

84 Application for Permission Kennedy [2001] EwHC Admin 851, [20].

85 Ibid, [AG98], note that in [AG93] the AG stated, 'Both parties - the мIB and the person injured - can, it is true, set out their respective views in the knowledge of the other's submissions'.

86 Ibid, [56].

87 See Clause 16 (4) мів UtDA 2017. This is also for the мів. Further, Section 69 (3) of the Arbitration Act 1996 provides: 'leave to appeal shall be given only if the court is satisfied(a) that the determination of the question will substantially affect the rights of one or more of the parties, (b)that the question is one which the tribunal was asked to determine, (c)that, on the basis of the findings of fact in the award - (i) the decision of the tribunal on the question is obviously wrong, or (ii) the question is one of general public importance and the decision of the tribunal is at least open to serious doubt, and (d)that, despite the agreement of the parties to resolve the matter by arbitration, it is just and proper in all the circumstances for the court to determine the question.

88 [2011] 12 WLUK $75^{2}$.
} 
negligence). This was rejected because this case was concerned with a question of fact rather than a question of law. ${ }^{89}$ Evidently from the above the MIB's process is one whereby appeals can be made, there is an arbitration process and errors of law can be challenged in the courts. The system seems to allow for speedier and more cost-effective resolution. Altering the process would need to be carefully considered in light of the positives and should not be done lightly.

However, more could be done to ensure transparency. The MIB could publicise further information concerning claims, such as the process involved, as well as the rationale behind their decisions. The мів could use the Financial Ombudsman Service (FOS) as an example. The Fos publicises its final decisions relating to complaints made against organisations, and how it handles those complaints. ${ }^{90}$ This is mandated in Schedule 11 of the Financial Services Act 2012, which inserts the requirement into Section 230A of the Financial Services and Markets Act 200o.91 The Fos does not publicise the personal data of individuals who make complaints, nor does it publish any early-stage discussion or settlement. Of course, there are differences here between Fos and the мIB process. The FOS process concerns complaints against other companies, whereas the мгв concerns claims to itself. However, it is submitted that the publication of the MIB's decisions would be beneficial. For example, publicising details of decisions could aide in refuting any discussions around bias. ${ }^{92}$ Moreover, in its 2011 consultation paper (after the publication of the Financial

89 See also Application for Permission Kennedy (n 82) [15], where the court noted that 'you cannot appeal on the facts'.

9o This is on the Fos website. See Fos, 'Ombudsman decisions' <https://www.financialombudsman.org.uk/data-insight/ombudsman-decisions> accessed 31 January 2020.

91 Section 230A Financial Services and Markets Act 2000 states ' "' (1) The scheme operator must publish a report of any determination made under this Part. (2)But if the ombudsman who makes the determination informs the scheme operator that, in the ombudsman's opinion, it is inappropriate to publish a report of that determination (or any part of it) the scheme operator must not publish a report of that determination (or that part). (3)Unless the complainant agrees, a report of a determination published by the scheme operator may not include the name of the complainant, or particulars which, in the opinion of the scheme operator, are likely to identify the complainant. (4)The scheme operator may charge a reasonable fee for providing a person with a copy of a report'.

92 This can be highlighted in the report by Richard Lloyd in the 'Independent Review of the Financial Ombudsman Service' who stated, 'the best safeguard against bias is its stronglyheld values about the need for fairness and impartiality, reinforced by transparency (for example the publication of casework data and decisions)...'. See Richard Lloyd, 'Report of the Independent Review of the Financial Ombudsman Service' <https://www.financialombudsman.org.uk/files/17748/Richard-lloyd-independent-review-2018.pdf> accessed ${ }_{31}$ January 2020. 
Services Bill 2011 by Parliament), the Fos noted that, 'Interested parties will be able to make their own informed judgement about the quality and content of our work, the appropriate consistency of our decisions, and how we are exercising our jurisdiction. Informed criticism of our work will help the ombudsmen to maintain high standards and develop our practice.93 This would therefore ensure adequate transparency and external discussion surrounding claims handling from the мів. It is further important due to the potential loss of awareness post the Brexit transition-period, where the right of action is removed, with limited visibility in terms of the MIB's claims handling. This, in fact, would be a significant increase in visibility compared to the мІв before Brexit, and may cause challenges such as an increase in cost, something that some responses to the Fos's consultation were concerned with. ${ }^{94}$

Moreover, the FOs has also noted concerns around cherry picking parts of their decisions, ${ }^{95}$ and a difficult balance was clearly faced by the Fos in terms of whether to publish the Ombudsman's determination, or to publish case summaries. With the latter, the FOs argued that it would provide significant additional administrative burden to summarise all decisions, with 'potential delays in the process' ${ }^{96}$ Although with the former, this 'might be confusing to the third-party reader. ${ }^{97}$ Overall, it is submitted that the publication of decisions by the мів would be a step forward for transparency. This could be mandated through legislation or through the MIB's own process. Of course, this would be a challenge for the мів in terms of cost and administrative burden, which needs to be weighed up with transparency. The MIB should undertake a consultation on the publication of decisions and which should involve the forms of such publication. ${ }^{98}$

\subsection{Privity}

Controversy has historically surrounded the enforcement of the MIв agreements by third parties who are not party to the agreements. Professor Lewis noted that, 'The use of private agreements which to which members of the public

93 See Fos, 'publishing ombudsman decisions: next steps' (September 2011) <https://www .financial-ombudsman.org.uk/files/17772/publishing-decisions-sep11.pdf $>$ accessed 31 January 2020.

94 FOS, 'Publishing Ombudsman Decisions: Summary of Responses' (January 2012) <https:// www.financial-ombudsman.org.uk/files/17771/Publishing-decisions-summary-2012.pdf> accessed 16 February 2020, 11.

95 Fos Next Steps (n 93), 8.

96 Ibid, 14.

97 Ibid.

98 As well as the issue surrounding confidentiality. This was discussed in the Fos consultation ibid, 17 . 
are not party can result...in the ignorance of rights that have been secured but also technical difficulties in seeking to rely upon them. ${ }^{99}$ The latter, in terms of seeking to rely on the agreements, is seemingly partially based on the issue of privity. As was noted in Albertv Motor Insurers' Bureau, ${ }^{100}$ 'The appellant is not a party to that agreement. Breach of it by the bureau does not under English law give her any right of action. A number of cases have been brought against the bureau by persons in a similar position to hers but the bureau has never, and says it never will, take the point that such a plaintiff has no cause of action:101 This was reiterated by a number of courts since. ${ }^{102}$ In Evans, the A-G was critical of the fact that the injured victim was not a party to the Agreement. ${ }^{103}$ It is notable however, that under Section 1 (1) of the Contracts (Rights of Third Parties Act) 200o, an individual can sue under a contract, if, 'the term purports to confer a benefit on him. The мIв UtDA 2017 expressly recognises the rights of third parties to claim under the agreement in clause 25 (4). This is a recognition of the fact that the UtDA provides such benefit that the MIB will compensate. In fact in Carswell $v$ Secretary of State for Transport, ${ }^{104}$ the court held that such a clause (which was also in the previous 2003 Agreement) ensured that this provision was fulfilled. It seems therefore that the issue surrounding privity is not one of practical significance for third parties as things currently stand, and there is not a legal hurdle here to surmount.

\subsection{EULaw}

EU law is important to examine, due to the potential change involving the UK leaving the EU's jurisdiction. It is worth repeating that the UK is subject to EU law until the end of the Brexit transition formatting here is off slightly - period at the beginning of 2021. The EU heavily regulates uninsured and untraced vehicles in its Sixth Consolidated Directive, ${ }^{105}$ providing a high level of coverage

99 Richard Lewis (n 18), 281.

100 Albert v Motor Insurers' Bureau [1971] 2 All ER 1345.

101 Ibid, 1354.

102 Persson v London Country Buses and another [1974] 1 All ER 1251, 1253.

103 Evans (n 69), [AG131], 'True, the MIB does not appear to refuse compensation despite the absence of any contractual relationship in law with the injured person in view of the fact that it is obligated to provide compensation on foot of the Agreement with the Secretary of State for Transport. However, should the injured person consider that he is adversely affected, he must, if necessary, institute judicial proceedings against the Secretary of State to force the latter to insist on compliance with the Agreement'.

104 Carswell $v$ Secretary of State for Transport [2010] EWHC 3230 (QB).

105 Directive 2009/103/EC of the European Parliament and of the Council of 16 September 2009 relating to insurance against civil liability in respect of the use of motor vehicles, and the enforcement of the obligation to insure against such liability. 
in article 10 required from the compensation body. When challenging any potential limitations of national law, there are a number of mechanisms that can be used. First to read national law in light of EU Law, ${ }^{106}$ second, to provide vertical direct effect of EU law against the state or its emanation, ${ }^{107}$ or third, if the member state fails to comply with EU, sue the state for breach (as happened in Delaney). ${ }^{108}$ This, however, is not an all-encompassing remedy, as suing the State requires, inter alia, a 'sufficiently serious breach' of EU law. ${ }^{109}$ Moreover, reading the agreements in light of EU law has been problematic. As noted by Lord Nichols in White $v$ White, a case involving the term 'ought to have known' in the UDA 1999, ${ }^{110}$ 'Had the МIв agreement been embodied in legislation, whether primary or secondary, the English court would have been under an obligation to interpret its provisions, as far as possible, in a way which gives effect to the directive.111 As the MIв agreement was not contained within legislation, a Marleasing interpretation could not be used. Nevertheless, the court arrived at the same result based on conventional interpretation.

Evidently, the мів has not provided the coverage required by EU law, and on occasion, has fallen short of the requirements. For example, in Delaney the SoSFT was sued successfully for Francovich damages for breach of EU law due to an exclusion contained in the UDA 1999 in relation to injuries caused in course or furtherance of a crime'. (Clause 6 (1) (e) (iii)) The мів later removed the exclusion from its agreement. This therefore shows that such a cause of action can be beneficial in providing increased protection for victims. Without such a cause of action, the victim would not have received damages from the мIв in Delaney (and potential future cases involving claims committed 'in course or furtherance of a crime'). Of course it is worth briefly noting here (this will be discussed in further detail below) that differences for victims have existed, and continue to exist, with the UK under the jurisdiction of EU law. In

106 Marleasing interpretation see Marleasing SA v La Comercial Internacional de Alimentacion $S A$ : C-106/89 (1990) C-106/89, ECLI.

107 See C-41/74 Van Duyn v Home Office [1974] ECR 1337. Note directives do not have horizontal direct effect (see C-152/84 Marshall $v$ Southampton and South West Hampshire Area Health Authority (Teaching) [1986] ECR 723).

108 C-6/go Francovich v Italian Republic [1991] E.C.R. I-5357 and Brasserie du Pêcheur SA v Federal Republic of Germany [1996] 10 WLUK 405.

109 See Ibid (Francovich).

110 See clause 6 (1) of the MiB UDA 1999.

111 White $v$ White, Evans $v$ Motor Insurers' Bureau and Mighell $v$ Reading [2001] 2 All ER 43, [21]. Also see Marleasing SA v La Comercial Internacional de Alimentación SA Case C-106/89 [1990] ECR I-4135. 
fact victims of untraced and uninsured drivers are currently treated less favourably. ${ }^{112}$

Nevertheless, EU Law remedies are only available whilst the UK is in the transition-period, or there is an agreement between the UK and EU encompassing this. The relationship between the EU and the UK beyond the transitionperiod is yet to be decided. If the UK is not required to follow EU law then a cause of action will not be present, meaning potentially less protection for victims and less scrutiny of the MIB agreements. Of course, it is worth noting here that the introduction of legislation does not necessarily mean that the protection of victims will increase, nor is legislation required to increase the protection of victims. We will need to address the potential for introducing legislation in the UK, although it is first important to examine the ACT who regulate this area in legislation.

An example of Uninsured Driving Legislation: The Australian Capital Territory

This article has so far analysed the UK's extra-statutory regime for the compensation of victims of uninsured or untraced drivers through the мів. We will now examine a potential alternative approach through the Australian Capital Territory (АCT). The АCT approach provides that compensation relating to uninsured or untraced drivers is contained in legislation (the Motor Accident Injuries Act 2019 (MAIA 2019)), and hence is an interesting comparator to the UK's approach. One significant difference is that the regulation of uninsured and untraced drivers in Australia is state specific, compared to Australia's federalised regulation of insurance law. This does not make a difference for the purpose of this article, as there are a number of similar approaches to the ACT approach, by other territories in Australia. For example, the Queensland approach is also contained in legislation through the Motor Accident Insurance Act 1994. Of course, a difference between UK and Australia is that the UK is currently in a transition-agreement with the EU, and is subject to EU rules. However, there is nothing in the Sixth Consolidated Directive which prevents legislation for uninsured or untraced vehicles rather than extra-statutory agreements. Moreover, the UK has not, as of yet, entered into an arrangement with the EU post-transition period, meaning that from 2021 the UK could instead follow an alternative approach such as ACT's.

112 This will be discussed further below. 
In the ACT, compensation for victims of uninsured and untraced vehicles is made by the nominal defendant. ${ }^{113}$ The nominal defendant pays accident claims from the nominal defendant's fund. (Section 329 (c) (ii) MAIA 2019 for 'uninsured motor vehicle' and Section 329 (c) (iii) MAIA 2019 for 'unidentified motor vehicle'). This is funded by insurance industry levies, as well as through recoveries such as in relation to costs from the responsible driver or person (Section 351 MAIA 2019). As the nominal defendant's role is provided within statute, there is no requirement for a private agreement between itself and the government. Interestingly, the ACT nominal defendant covers three types of vehicle, uninsured vehicles, unidentified vehicles, and vehicles which have an unregistered vehicle permit. ${ }^{114}$ It is the first two of these which are important for the purpose of this study as the UK does not have the third. In relation to uninsured vehicles, Section 326 MAIA 2019 provides, inter alia, that:

(1)This section applies if-(a)a personal injury is caused by a motor accident; and(b)at the time of the motor accident, the motor vehicle involved in the motor accident-(i)had a sufficient connection with the $A C T$; and(ii)was an uninsured motor vehicle; and(c)the motor accident happened anywhere in Australia...2)The nominal defendant is liable in relation to the personal injury as if-(a)an MAI policy were in force for the motor vehicle; and(b)the nominal defendant were the $M A I$ insurer for the MAI policy.

This therefore provides liability for the nominal defendant equivalent to an insured vehicle and puts the nominal defendant in the position of a vehicle's insurer. Moreover, whereas in the UK a judgment would need to be obtained against the person responsible for an accident, ACT legislation does not provide that a judgment needs to be obtained against the person responsible. As noted under Section 236 (1) MAIA 2019:

If a motor accident claim is made against the nominal defendant, the nominal defendant may deal with the motor accident claim, and any proceeding relating to the motor accident claim, in the way the nominal defendant considers appropriate including - (a) settling or compromising the motor accident claim; and (b) bringing and prosecuting a proceeding

113 In the ACT, the nominal defendant is the Australian Capital Territory Insurance Authority, a statutory office rather than a private company.

114 For liability of the nominal defendant for Unregistered Vehicle Permit see Section 324 MAIA 2019 . 
under this Act for the motor accident claim and settling or compromising the proceeding.

Helpfully the MAIA 2019 further defines an 'uninsured vehicle', inter alia, as, ' $a$ motor vehicle for which there is no MAI policy in force' (Section 325 (1) (a)). This, therefore, provides some limited clarity in terms of what is an 'uninsured vehicle', particularly with the fact that it includes 'no MAI policy in force'. Moreover, it is evident that the MAIA 2019 is restrictive of defences that insurers can use. For example, under Section 310, the insurer has 'no power to cancel a MAI policy'.

For untraced vehicles Section 328 MAIA 2019, inter alia states: (1) 'if- $(a) a$ personal injury is caused by a motor accident; and $(b)$ the motor vehicle involved in the motor accident is an unidentified motor vehicle; and (c) the motor accident happened in the MAI. (2) The nominal defendant is liable in relation to the personal injury as if - (a) a MAI policy were in force for the motorvehicle; and (b) the nominal defendant were the MAI insurer for the MAI policy. The MAIA 2019 further provides a definition of 'untraced vehicle' within Section 327 (1) which, inter alia, states that an unidentified vehicle, '(a) means a motor vehicle that cannot be identified after reasonable inquiry and search'. Again this provides some limited clarity as to how an untraced vehicle is determined.

Section 263 (1), inter alia, states: 'If a motor accident claim is made against the nominal defendant, the nominal defendant may deal with the motor accident claim, and any proceeding relating to the motor accident claim, in the way the nominal defendant considers appropriate including - (a) settling or compromising the motor accident claim'. This can therefore be likened to the MIB in relation to untraced drivers. Nevertheless, a court proceeding can be brought later (in cases of uninsured vehicles against the nominal defendant and the person uninsured, (Section 272 (2) MAIA 2019) or in cases of unidentified vehicles, against the nominal defendant only (Section 272 (3) MAIA 2019)). However, a compulsory conference between the parties must occur before a claimant brings a case which may contain a mediator. This does not guarantee a settlement although the each participant must 'actively take part in an attempt to settle the motor accident claim' (Section 262 (1) (b) MAIA 2019). Unlike the UK, there is not an arbitration hearing prior to court action for victims of untraced drivers, meaning that the claimant does not have the burden of proving an error in law to be successful in court. Consequently, there is an additional layer of transparency, as arbitration proceedings are not publicised. It is submitted that this is an advantage, particularly for victims of unidentified drivers, compared to the UK. However, this could mean an issue for cost. Where a claim is settled at arbitration, it would evidently be cheaper than court action. 
Moreover, the use of courts may be a challenge due to the time taken to determine the results of claims.

As noted previously in this article, a criticism of the MIв was made in the UK case of Delaneyv Secretary of State for Transport ${ }^{115}$ as there were ' $n o$ documents' for introduction of the crime exception, and since this is a private agreement, parliamentary debates did not assist in the court's interpretation. However, in the АСт case of Cook $v$ Nominal Defendant, ${ }^{116}$ a debate in the АС T Parliament proved useful in determining the time limit provision within the Road Transport (Third Party Insurance) Act 2008 (RTT PIA 2008) which regulated this area before the MAIA 2019. The court noted the time limit provision had previously provided no flexibility, with the nominal defendant unable to waive the three-month time limit. Also, there were concerns in the Legislative Assembly about this bar, ${ }^{117}$ and it was proposed that on two occasions that this bar should be lifted. ${ }^{118}$ The court therefore noted that as the final RTTPIA 2008 provided some flexibility without any exceptions, this was wider than what was proposed. This highlights that the use of legislative debate can be useful for the court in interpreting provisions.

Furthermore, in terms of transparency, the MAIA 2019 notably does not provide for arbitration concerning the determination of awards. Instead, the MAIA 2019 provides that both unidentified and uninsured vehicles are to be treated as if they are insured for the purpose of claiming against the nominal defendant. The same process would be followed as if the vehicle was insured, which includes mandatory conference calls (part 5.7.2 MAIA 2019), mandatory final offers (part 5.7.3 MAIA 2019) and potential court proceedings (part 5.7.4 MAIA 2019). This provides the opportunity for court action, whilst providing an opportunity for settlement before the case goes to court. It is submitted that this is arguably more transparent than the UK approach, and is fairer due to the treatment of victims in the same way (with exceptions for time limit). However, if an issue was settled prior to court action, such as through the mandatory conference call, it is unlikely that this would be publicised, meaning limited transparency. Of course, the MIB is also not required to publicise when it settles a claim.

\footnotetext{
115 Delaney (n 10).

116 [2015] ACTSC 278.

117 See the debates of the Legislative Assembly for the ACT, 20 August 2008 at $3300-3301$ cited in Ibid, [21].

118 Such as where a police accident report was not filled within three months and where there was an incorrect file of a claim to the insurer with the wrong number plate and it turned out the vehicle was uninsured.
} 
It is important to note that the Motor Accident Injuries Commission ('the MAIA Commission') was introduced in the ACT through Section 22 MAIA 2019. The MAIA Commission has a number of functions (see Section 25 MAIA 2019), with one of them contained in Section 25 (f) 'to provide, or facilitate or regulate the provision of, information to the public about the motor accident injuries insurance scheme, causes of motor vehicle accidents... and motor accident claims, and dispute resolution'. In Section 236 (2) MAIA 2019 the nominal defendant must provide to the Motor Accident Injuries Commission, 'the reports that the MAI commission reasonably requires about anything done by the nominal defendant under this section'. Section 236 (1) was discussed above and provides, inter alia, that the nominal defendant 'may deal with the motor accident claim' (Section 236 (1)). Consequently, the requirement in Section 236 (2) provides an additional layer of transparency in the ACT. This could be considered in the UK, although, it is submitted, that the publishing of decisions by the мгв such as the approach taken the FOS (as discussed above) could provide needed transparency.

What Next?

This article has so far found that while the UK's system for compensating victims of uninsured and untraced drivers is beneficial for cost implications and expertise, there are challenges surrounding transparency and the provision of adequate protection for third party victims, particularly post-transition period. The ACT approach provides an interesting contrast to the UK due to additional transparency. Although, whether this would work in the UK is uncertain. It is necessary, therefore, to examine whether a statutory system would be beneficial, or whether there are alternatives. It is clear that the мів agreements do not currently provide complete protection for accident victims, despite the agreements being concerned with providing compensation. However, it is difficult to know whether claimants fall through the gaps in the agreements and the extent of this, which can linked to the absence of transparency surrounding claims. Moreover, notwithstanding limits for statutory coverage of victims of insured vehicles, ${ }^{119}$ the difference in treatment of accident victims is evident. For example, as noted by Steven Gee:

Victims can claim in arbitration against the $M I B$ under a scheme which in certain respects gives victims less than what can be available in court.

119 See exclusion clauses within Section 148 (2) RTA 1988. 
For example, subrogated claims are not permitted. Replacement car schemes which promptly provide a replacement vehicle to a victim work in insurance cases through the provider being subrogated to a claim for its charges, but in practice are not available to a victim who has to rely on a claim against the $M I B^{120}$

Further, in the UDA 2015, there are 'preconditions to the MIB's obligation',121 including in relation to the form of claims, ${ }^{122}$ joining the МІв as a defendant, ${ }^{123}$ prosecution of proceedings, ${ }^{124}$ and assignment of judgments, settlements, and undertakings. ${ }^{125}$ Moreover, the UtDA 2017 contains a number of procedural requirements and time limits, ${ }^{126}$ and a limitation in terms of property damage. ${ }^{127}$

As noted previously, differences between the treatment of victims have been limited to a certain extent due to EU law. Consequently, the removal of a cause of action could mean that victims have less opportunity to challenge the agreements. However, it is also notable that the limitations and differences between the treatment of victims have been present with the UK under the jurisdiction of the EU. In fact, the High Court in Roadpeace denied a breach of EU law relating to a time limit clause in the previous UtDA 2003, ${ }^{128}$ noting that, 'it is evident that there are differences in their circumstances (victims of insured, uninsured, and untraced vehicles)'.129 This means that an EU cause of action

120 Steven Gee QC, 'Suing persons unknown, the EC Motor Insurance Directive and Cameron v Liverpool Victoria' (2019) 6 Journal of Business Law 416, 418-419. Also see McCallv Poulton [2008] EWCA Civ 1313, involving the denial of a subrogated claim by the мів for credit hire charges (under clause 6 (1) (c) of the 1999 UDA) and (clause 17 (1) of the 1999 UDA which allowed deductions by the мг for any claims paid by another insurer). Questions concerned whether the мів Agreement should be read in light of (article 1 (4)) of the Second Council Directive 84/5/EEC of 30 December 1983 on the approximation of the laws of the Member States relating to insurance against civil liability in respect of the use of motor vehicles). This case was settled before it reached the European Court of Justice.

121 See the UDA 2015 (n 4), p9.

122 Ibid, clause 12.

123 Ibid, clause 13 .

124 Ibid, clause 14.

125 Ibid, clause 15 .

126 See for example 'obligations upon the claimant' in clause 10 UtDA 2017 (n 5).

127 Ibid, clause 7 .

128 Clause 4 (c) to (e) UtDA 2003 (n 70).

129 Roadpeace $v$ Secretary of State for Transport $v$ Motor Insurer's Bureau [2017] EWHC 2725 (Admin). The court referred to Evans $v$ Secretary of State for the Environment, Transport and the Regions 2006] EWHC $322(\mathrm{QB})$ (where the court had found a breach of EU law in terms of time limits). The High Court noted [119], 'Evans does not suggest that there should be no differences between the provisions for insured and identified drivers and unidentified 
did not always prevent differences in the treatment of victims. ${ }^{130}$ However, it has certainly provided the opportunity for victims to challenge the agreements in court due to breaches of EU law, with some success such as in Delaney and Evans. Consequently, with the potential removal of a cause of action post transition-period, it is arguable that the cause of action should be replaced to ensure that the agreements are kept under continued scrutiny and protection is increased.

Of course, there is nothing to prevent legislation from including exclusions. However, differences between the protection offered to victims of uninsured and insured vehicles would be more noticeable and would be open to more scrutiny. Moreover, introducing a system to compensate the victims of uninsured and untraced vehicles in legislation would provide some advantages. For example, through signifying the equivalence of accident victims from uninsured and untraced vehicles, with victims of insured vehicles, as shown in the ACT approach. However, it is questionable whether the equivalence of third parties could instead be signified in the мгв agreements, without the need for statute. Greater transparency in discussions between the DfT and the MIB, as well as greater consultation with those external to the MIB and DfT could also signify equivalence without resorting to legislation. It is evident, as noted above, that the мів undertake consultation in relation to their agreements. However, further consultation would undoubtedly be welcome.

Moreover, it is questionable whether the introduction of a statutory мів (similar to the АСт approach) would fit well in the UK due to the need for cooperation. The UK's approach has been in place since 1946 with focus on co-operation between the insurance industry and government. The removal of agreements, and therefore forcing the MIB to compensate through legislation, could mean an absence of goodwill from the insurance industry. This is not only with motor insurance but also other forms of insurance. ${ }^{131}$ Moreover, it could mean insurers attempting to find loopholes in any statutory scheme when a claim is made. This would also be a significant challenge, as after the transition-period there may not be direct effect of EU law to fill some of the gaps in a statutory scheme. Of course, it is difficult to know whether, with the removal of direct effect, insurers would attempt to find loopholes in the

drivers.' The court further noted that the principle of equivalence was not offended by differences, noting, [120], 'Equivalence does not require that the provisions be identical; these are equally favourable for the differing circumstances to which they need to apply.'

130 The мів, for example has removed the 'crime exception', it has further removed a number of the time limits which were in place in 1999.

131 See for example Lewis's ( $\mathrm{n} 18)$ article which discusses some of the co-operation between the state and the insurance industry not to enforce legal rights. 
non-statutory agreements in the future anyway. However, it remains that the introduction of a statutory мІв and the removal of co-operation requires careful consideration, with the impact considered. Whilst the author recognises that the law should not be developed with only insurance interests in mind, and if a statutory scheme was necessary, this would undoubtedly override such interests, it is submitted that this is not evident here. The introduction of a new statutory MIв, whilst providing some benefits in terms of transparency, is not necessary to provide increased protection to third parties. The DfT could push for greater protection without statutory intervention. ${ }^{132}$

Further, the insurance industry has significant expertise of claims processes, pricing, and risk, meaning that working with the insurance industry is important to ensure that significant disruption is not caused in the conduct of insurance business. Of course, any changes made through legislation would not necessarily mean that the insurance industry would not have a role and could not provide expertise, as was noted above. Moreover, the MIB's current challenges involving Brexit are substantial, and therefore the introduction of a statutory mechanism would provide less time to focus on this. Consequently, substantial reform to the MIв through statute could be examined at a later date. The мів has been in place for a significant period of time, and whilst there have been some challenges, reform is probably not a high priority. As noted by Mr Justice McKay, 'the MIB has operated efficiently, successfully and to general approval for over 60 years. It has attracted added responsibilities, for example, the 1969 Untraced Drivers' Agreement. The risk that it would effectively disappear and not be replaced by some equivalent institutional body, in my judgment, is so remote as to be capable of being discounted entirely for present purposes'.133 This statement occurred pre-significant case law such as Delaney and Roadpeace, as well as Brexit (whereby a cause of action is removed). However, it is submitted that it is unlikely that this would have a significant effect in calling for the MIB to be put on a legislative footing. Changes could be made to the agreements without statute.

It is notable, however, that the introduction of a statutory мів may mean the removal of flexibility. The SoSFT and the Miв can amend the agreements with supplementary agreements, without the need to go through a potentially long parliamentary process. ${ }^{134}$ A difficulty with this, however concerns

\footnotetext{
132 Also see the previous discussion around the compensation of victims from untraced drivers and which was introduced by the мів.

133 Mr Anthony Nathaniel Bennett v Mr Leonard John Stephens [2010] EWHC 2194 (QB), [19].

134 See, for example, the мів UDA Supplementary Agreement which, inter alia, removed the terrorism exception and vehicle damage exception from the previous agreements, see мів 'The Supplementary Agreement (UDA)' (2017) <https://www.mib.org.uk/media/
} 
exclusions and the absence of transparency. ${ }^{135}$ An approach that mixes the м Iв agreements with legislation could provide a solution to some of the challenges in the agreements, such as the main exclusions, which could be provided in statute. This would ensure some flexibility for the м г в to determine its process and requirements, with greater transparency and oversight regarding important elements in legislation. However, this could cause confusion with regulation in two places, and further risking co-operation. An alternative approach could be to ensure that there is significant transparency going forward when agreements are introduced through the publication of discussions. Moreover, increased collaboration with various organisations, and further consultation are also important. This, it is submitted, would be a less drastic approach than legislating, and would solve some of the issues surrounding transparency, without risking the relationship between the мів and the government.

The ACT approach for claims is a potential alternative to the much-criticised UK approach. ${ }^{136}$ A particular issue, it seems, involves arbitration and the appointment of arbitrators. Consequently, the ACT approach, which provides the opportunity of court action, could be a solution. Whilst arguably proving costly and untimely if court action was more likely, the use of a compulsory conference mechanism to try and solve disputes before they go to court may indeed limit this. Again, the introduction of a different mechanism for claims would be a significant overhaul for the MIв. This could mean the potential for higher costs, and therefore likely unpopularity with the insurance industry and motorists, with the costs being passed on through insurance premiums. This article has highlighted that despite concerns surrounding the MIB's approach to claims, particularly concerning untraced drivers, the courts have not found that this approach is illegal.

It is therefore submitted that while the current approach concerning claims is not entirely satisfactory, a radical overhaul would need to be carefully determined in light of the time taken and cost. It seems overall that the АСт approach, while an interesting alternative, should not be introduced lightly. There are several factors involved which would need to be considered, and it seems that some of the challenges highlighted in this article could be addressed through greater transparency in the way the M Iв operates. The мів should consider providing more transparency for claims overall, with more

350345/2017-supplementary-uninsured-drivers-agreement-england-scotland-and-wales .pdf > accessed o3 April 2020.

135 Such as the crime exception as noted above.

136 As was noted above. 
detail in terms of how claims are handled, any complaints received resulting from claim handling, and how the law is applied to claims that are received. The UK could take the Fos as an example in providing the detail of claims. This would ensure greater transparency and scrutiny of the мів. However, the мів should consult on this in terms of the detail to be provided, and should further consider the potential cost and administrative burden. Legislation could also be introduced as there is currently with the Fos.

\section{$7 \quad$ Conclusion}

The UK's system of compensating victims for damages resulting from uninsured or untraced drivers is complex. The мів has been in place for over 70 years and has been at the centre of various controversies. There has been criticism of difficulties surrounding coverage, enforcement and transparency. One of the reasons behind this is undoubtedly the private nature of the мів. Transparency is certainly a significant issue, the rationale behind the introduction of certain provisions is unclear. Moreover, the procedure for claims in terms of untraced drivers also lacks transparency, along with the requirement of arbitration for appeals. Whilst the MIB's claims procedure has been criticised by some claimants, it seems that the procedure has some benefits around the cost and timeliness of proceedings.

Having examined the approach from the ACT as a potential alternative option for the UK, it is evident that the АСТ approach provides greater transparency, and clarity in terms of how an uninsured vehicle is defined. The equivalence of uninsured and untraced vehicles with insured vehicles could be welcomed in the UK, although it is questionable as to whether this would require legislation. Legislation in the UK, however, would be a significant change to what is, and has been in place for more than 70 years. Moreover, it is questionable whether there will be an appetite for such an approach once the UK leaves the EU post-transition, where the absence of case law challenging noncompliance with EU law will reduce the pressure to reform. However, the absence of a direct right of action could increase the appetite for reform due to the absence of being able to challenge the agreements, and obtain a remedy against the state.

Overall, it is submitted, that a legislative approach in terms of the м Iв could and should be considered going forward to meet the longer-term need for reform. However, other options such as increasing transparency are a less radical but more immediate way of reform which could and should be discussed. The introduction of a statutory м Ів would require a significant and challenging 
shift in emphasis from the UK. The probability of the further protective layer provided by EU law being removed has brought this very clearly into focus, highlighting the importance of such a discussion going forward to maintain the protection of third party victims. 